\title{
Correspondence
}

http://dx.doi.org/10.11646/phytotaxa.202.3.9

\section{Typification of the names and taxonomic status of selected vascular plant taxa de- scribed by Max Eugen Heinrich Grütter}

\author{
ARTUR PLISZKO ${ }^{1 *} \&$ WALDEMAR HEISE ${ }^{2}$ \\ 'Department of Plant Taxonomy, Phytogeography and Herbarium, Institute of Botany, Jagiellonian University in Kraków, Kopernika 31, \\ 31-501 Kraków,Poland; e-mail: artur.pliszko@uj.edu.pl \\ ${ }^{2}$ Department of Plant Ecology, Institute of Botany, Jagiellonian University in Kraków, Lubicz 46, 31-512 Kraków, Poland \\ * author for correspondence
}

Max Eugen Heinrich Grütter (30 March 1865-31 March 1897) was a German botanist interested in floristics and taxonomy of vascular plants and mosses (Abromeit 1897). He conducted intensive floristic studies on the territory of the former West and East Prussia, especially in the former West Prussian Province Schwetz (now north-central Poland) where he lived in the small village of Luschkowko (Grütter 1892, 1895a, 1895b, 1895c, 1897). His numerous findings had been frequently cited in "Flora von Ost- und Westpreussen" by Abromeit et al. (1898-1940). In 1890-1891, in the course of the floristic expeditions in the former West Prussian Province Schwetz, Grütter found interesting vascular plants which he deemed as new to science. The names of these taxa were validly published in Deutsche botanische Monatsschrift (Grütter 1892).

In 2014, during the taxonomic revision on herbarium materials stored at the Herbarium of Institute of Ecology and Environment Protection of Nicolaus Copernicus University in Torun (TRN), the original herbarium specimens of three of the vascular plant described by Grütter (1892) were found. The names of these taxa are typified and their current taxonomic status is given. Unfortunately, the types of three other validly published names, Carex ericetorum var. tenella Grütter (1892: 69), Lepidium ruderale f. incanum Grütter (1892: 68), and Verbascum nigrum f. leucerion Grütter (1892: 69), have not been found during the revision, and they seem to be lost or destroyed.

\section{Pulsatilla vernalis f. glabrescens Grütter (1892: 67).}

Lectotype (designated here):-POLAND. Westpreussen, Kreis Schwetz: Abgeholtze Waldfläche des Schewinkoer Waldes bei Blondzmin, 12 Apr 1890, M.E. Grütter s.n. (TRN!).

Status: This name is a heterotypic synonym of Anemone vernalis Linnaeus (1753a: 538).

Anemone sylvestris f. biflora Grütter (1892: 68).

Neotype (designated here):-POLAND. Westpreussen, Kreis Schwetz: bei Topolinken, May 1893, M.E. Grütter s.n. (TRN!).

Status: This name is a heterotypic synonym of Anemone sylvestris Linnaeus (1753a: 540).

Artemisia vulgaris var. macrocephala Grütter (1892: 68).

Lectotype (designated here):-POLAND. Westpreussen, Kreis Schwetz: bei Luschkowko, 20 Sep 1890, M.E. Grütter s.n. (TRN!).

Status: This name is a heterotypic synonym of Artemisia vulgaris Linnaeus (1753b: 848).

\section{Aknowledgements}

The first author would like to thank PhD Radosław Puchałka, the curator of the Herbarium of Institute of Ecology and Environment Protection of Nicolaus Copernicus University in Torun (TRN), for providing the access to the collections. 


\section{References}

Abromeit, J., Neuhoff, W. \& Steffen, H. (1898-1940) Flora von Ost- und Westpreussen. Komissionsverlag Gräfe und Unzer, Berlin, Königsberg, 1248 pp.

Abromeit, J. (1897) Biographische Mitteilungen über Grütter. Jahres-Bericht des Preussischen Botanischen Vereins 1896/1897: 74-76.

Grütter, M. (1892) Neue botanische Beobachtungen in Westpreussen in den Jahren 1890 und 1891. Deutsche botanische Monatsschrift 10: 67-70.

Grütter, M. (1895a) Die Flora des Kreise Schwetz in Westpreussen. Deutsche botanische Monatsschrift 13: 9-11.

Grütter, M. (1895b) Die Flora des Kreise Schwetz in Westpreussen. Deutsche botanische Monatsschrift 13: 76-78.

Grütter, M. (1895c) Beiträge zur Moosflora des Kreises Schwetz. Bericht des Westpreussischen Botanisch-Zoologischen Vereins 18: 397-407.

Grütter, M. (1897) Beitrag zur Kenntnis der Flora des Kreise Oletzko und Goldap. Schriften der Physikalisch-Ökonomischen Gesellschaft zu Königsberg in Preussen 38: 48-51.

Linnaeus, C. (1753a) Species Plantarum 1. Laurentii Salvii, Stockholm, 560 pp.

Linnaeus, C. (1753b) Species Plantarum 2. Laurentii Salvii, Stockholm, pp. 561-1200. 